\title{
Evaluation of a Cow-Side Test for Detection of Gram-Negative Bacteria in Milk from Cows with Mastitis
}

\author{
By S. Waage ${ }^{1}$, P. Jonsson ${ }^{2}$ and A. Franklin ${ }^{3}$
}

${ }^{1}$ National Veterınary Institute, Oslo, Norway, ${ }^{2}$ Department of Veterinary Microbiology, Section of Clinical Microbiology, Swedish University of Agricultural Sciences, Uppsala, Sweden, and ${ }^{3}$ National Veterinary Institute, Uppsala, Sweden.

\begin{abstract}
Waage, S., P. Jonsson and A. Franklin: Evaluation of a cow-side test for detection of Gram-negative bacteria in milk from cows with mastitis. Acta vet. scand. 1994, 207-211. - A modified Limulus amebocyte lysate (LAL) cow-side test was evaluated under field conditions. The principle of the test is to visualize reactions between test components and endotoxin from the cell wall of Gram-negatıve bacteria. The practıcal purpose is to detect such bacteria in mastitic milk. Secretions from 789 udder quarters with clinical mastitis were examined by the LAL-test. Parallel quarter milk samples were sent to a mastitis laboratory for microbıological examination. Eleven veterinary surgeons in three veterinary districts in Norway performed the field investigations. Results of the LAL-test and culture agreed in $93 \%$ of all milk samples tested, agreement measured by kappa being 0.63 . The sensitıvity of the test in detecting Gram-negatıve bacteria was $63 \%$, while the specificity was $97 \%$. The predictıve value of a positive test result was $70 \%$, the figure being somewhat higher $(75 \%)$ when the material was limited to milk samples without antibıtic resıdues. The predictive value of a negative test result was $95 \%$. The LAL-test is considered to constitute a valuable cow-side test for the veter1nary practitioner, aiding the selection of antıbacterial drug of choice for the initial treatment of clinical mastitis.
\end{abstract}

Limulus amebocyte lysate test; bovine; diagnostics.

\section{Introduction}

In order to achieve optimal results from treatment of mastitis, knowledge of the causal organism and its antibiotic sensitivity is necessary. However, treatment of acute clinical mastitis has to be initiated as soon as possible, and before results of culture and antibiotic susceptibility tests are available. Therefore, drug choice must be based on clinical suspicion of the causal organism.

Reports from different countries indicate that the relative importance of Gram-positive versus Gram-negative bacteria in causing clinical mastitis is fairly constant. Extensive surveys in Scandinavia (Waage et al. 1990, Svensk Husdjursskötsel 1991), Switzerland (Schallibaum 1993), UK (Central Veterinary Laboratory 1981), and Ohio, USA (Bartlett et al. 1992) all show that Gram-positive cocci dominate, while coliforms are isolated in 10 to $20 \%$ of clinical cases.

Clinical signs alone are insufficient to differentiate between infections caused by Grampositive and Gram-negative bacteria respectively (Funke 1983, White 1987). From a therapeutic point of view, the possibility of deter- 
mining, in the field, whether an infection is caused by Gram-positive or Gram-negative bacteria, would represent a step forward.

This report presents the results of a clinical trial of a modified Limulus amebocyte lysate (LAL) test for the rapid detection of Gramnegative bacteria in mastitic milk.

\section{Materials and methods}

\section{Test presentation}

The LAL-test is the most sensitive in vitro test available for determination of endotoxin. The test has been used for pharmaceutical, clinical and industrial purposes, as well as in research (Roth et al. 1989).

The method is based on the coagulation mechanism of the blood of the horseshoe crab (Limulus polyphemus). The coagulation cascade involves three or more protein factors, two of which are proteolytic enzymes, and the third a coagulation protein (coagulogen) (Roth et al. 1989). These factors can be found intracellularly in amebocytes. The amebocytes are equivalent to the erythrocytes of mammals, and can be obtained in inactivated form in extracts of Limulus amebocytes. When endotoxin (lipopolysaccharide) from the cell wall of Gram-negative bacteria comes into contact with lysate of amebocytes, various coagulation proteases are activated, and the coagulogen is polymerized under formation of a gel. The activation of the coagulation cascade causes turbidity which can be visualized. In order to increase the sensitivity of the reaction, a chromogenic substrate is coupled to paranitroaniline (PNA).

When the substrate is split by the proteins in the cascade, PNA is liberated. The free PNA absorbs yellow light. The yellow colour obtained in endotoxin positive samples can be seen by the naked eye.

The LAL-test has previously been used as a cow-side test to detect endotoxin from Gram- negative bacteria in milk of infected udder quarters (Jonsson et al. 1985). By means of a modified chromogenic LAL-test (Jonsson \& Franklin, to be published), the incubation period has been reduced to 15 minutes, making the test more suitable for use in veterinary practice.

\section{Test performance}

Glass bottles $(12 \times 32 \mathrm{~mm}$, Chromacol, Scantec, Partille, Sweden) containing lyophilized Limulus amebocyte lysate (Chromogenix AB, Gothenburg, Sweden) were used.

Milk samples were collected lege artis in plastic milk tubes. Using pyrogen free $1.0 \mathrm{ml}$ syringes (Becton and Dickinson, Stockholm, Sweden), $0.1 \mathrm{ml}$ of the milk was injected into a pyrogen-free glass bottle $(12 \times 32 \mathrm{~mm}$, Chromacol, Scantec, Partille, Sweden) containing $0.9 \mathrm{ml}$ distilled and pyrogen-free water. The bottle was placed in a boiling waterbath for two minutes (immersion heater) followed by cooling in tap water. Thereafter $0.1 \mathrm{ml}$ of the diluted sample was transferred, by a second syringe $(1.0 \mathrm{ml}$, Becton and Dickinson, Stockholm, Sweden), into a glass bottle containing LAL and substrate (see above). This bottle was kept in a $37-40^{\circ} \mathrm{C}$ water bath (bucket) for 15 minutes. The colour of the solution was then immediately recorded by the naked eye. If yellow, the test was regarded as positive (i.e. containing endotoxin), and if the colour was unchanged, the test was regarded as negative (absence of endotoxin).

\section{Field trial}

A field trial was carried out in three veterinary districts in Norway. Eleven veterinary surgeons participated.

The inclusion criteria were as follows: Cows in their first to third lactation with acute clinical mastitis within 6 months after parturition, and not treated for mastitis earlier in the current 
Table 1. Distribution of 781 cases of acute clinical mastitıs in relation to outcome of Limulus amebocyte lysate (LAL) test and results of culture*.

\begin{tabular}{ccccc}
\hline & \multicolumn{4}{c}{ Culture } \\
\cline { 2 - 5 } LAL-test & E. coll & $\begin{array}{l}\text { Other } \\
\text { Gram- }\end{array}$ & Gram+ & $\begin{array}{c}\text { No growth } \\
\text { of bacteria }\end{array}$ \\
\hline+ & 51 & 6 & 22 & 2 \\
- & 24 & 9 & 612 & 55 \\
\hline
\end{tabular}

Observed proportion agreement: $(51+6+612+55) / 781=92.7 \%$

Predictive value of a positive test result: $57 / 81=70.4 \%$

Predictive value of a negative test result: $667 / 700=95.3 \%$

Sensitıvity, detecting Gram-negative bacteria: $57 / 90=63.3 \%$

Sensitivity, detecting $E$. coli: $51 / 75=68.0 \%$

Specificity: $667 / 691=96.5 \%$

* A mixed flora grew from quarter milk samples from eight cases which are not included in the table.

lactation period. These criteria were established partly because the LAL-test trial was combined with a mastitis therapy trial.

The material comprised 789 cows. In cows with two or more affected quarters, the quarter with the most marked clinical signs was chosen for investigation. Before treatment, the milk secretion was examined by the LALtest. In addition, quarter milk samples were collected and sent to the mastitis laboratory at The National Veterinary Institute, Oslo, Norway.

Isolation and identification of bacteria from quarter milk samples were carried out according to the recommendations of the International Dairy Federation (International Dairy Federation 1981). In addition, all samples were examined for the possible presence of antibiotic residues. A prerequisite for inclusion in the trial was that antibiotics had not been administered before examination. However, antibiotic residues were found in 61 samples.

\section{Results}

The LAL-test was positive in 82 cases and negative in 707 (Table 1).
A mixed flora grew from 8 samples. The outcome of the LAL-test was impossible to evaluate in relation to these samples, and they were therefore excluded from the calculations.

In $724(92.7 \%)$ of the remaining 781 cases, the outcome of the test agreed with the result of culture. Agreement measured by kappa (Martin et al. 1987) was 0.63 .

The test result was considered positive in 81 $(10.4 \%)$ of the 781 cases. Escherichia coli or other Gram-negative bacteria were found in 57 of the corresponding quarter samples. The predictive value of a positive test result was, consequently, $70.4 \%$. Culture of the remaining samples either produced Gram-positive bacteria (22 samples) or no microorganisms at all (2 samples). Of the Gram-positive bacteria, 11 were $S$. aureus, 4 Streptococcus dysgalactiae, 3 Actinomyces pyogenes, 3 coagulasenegative staphylococci, and 1 Streptococcus uberis.

The results of 700 tests were considered negative. In $667(95.3 \%)$ of the corresponding quarter samples the result of culture was in accordance with the test outcome, as the findings were either growth of Gram-positive bac- 
teria (610 samples) or yeasts (two samples), or no growth of microorganisms (55 samples). Consequently, the predictive value of a negative test result was $95.3 \%$. The Gram-positive bacteria were $S$. aureus (342 samples), coagulase-negative staphylococci (83 samples), Str. dysgalactiae (131 samples), Str. uberis (15 samples), other streptococci (29 samples), $A$. pyogenes (5 samples), and various other bacteria (5 samples).

The sensitivity of the LAL-test in detecting Gram-negative bacteria was $63.3 \%$, i.e. the test result was positive in 57 of 90 cases where Gram-negative bacteria grew from corresponding quarter samples. E. coll was found in 75 samples. The sensitivity of the test regarding detection of this species alone was $68.0 \%$. Pseudomonas $s p$. was found in 3 samples. The LAL-test result was negative in these cases. In 4 cases where enterobacteria were found in the quarter sample, though the LALtest result of the corresponding sample was negative, just a few (2-7) colonies appeared on the agar plate. In 6 cases with a negative LALtest result, the possibility of the growth of enterobacteria, though in pure culture, being due to contamination could not be ruled out. In these cases, a mixed flora, often dominated by enterobacteria, grew from at least 1 of the other quarter samples from the same cow.

In 667 of 691 cases where laboratory examination revealed either Gram-positive bacteria, yeasts, or no growth at all, the LAL-test result was negative. The specificity of the test was, thus, $96.5 \%$.

After exclusion of the 61 cows with antibiotic residues in the milk, the observed proportion agreement between LAL-test and laboratory results was $93.1 \%$. Kappa was 0.66 . The predictive value of a positive test result was $74.7 \%$, and that of a negative test result $95.2 \%$. The sensitivity of the test in detecting Gram-negative bacteria was $64.4 \%$ (for $E$. coli alone $69.4 \%$ ), while the specificity was $97.0 \%$.

The frequency of disharmony between the outcome of the LAL-test and the result of culture did not differ for 9 of the 11 participating veterinary surgeons. The remaining 2 veterinary surgeons considered together had a significantly higher frequency of discrepant results than the others as a group, $18.8 \%$ versus $6.8 \%$ ( $\mathrm{p}<0.05$, chi-square test).

The trial lasted for just over a year. There was no significant difference between the first and second half-year regarding the degree of harmony between LAL-test and culture results (92.4\% and $93.8 \%$ respectively).

\section{Discussion}

In the present investigation the outcome of almost 800 LAL-tests performed by veterinary surgeons was compared with microbiological findings in parallel quarter milk samples examined at a mastitis laboratory. An overall agreement of $93 \%$ was found between test and laboratory results. Kappa, a measure of the degree of agreement beyond chance, was 0.63 .

The predictive value of a positive test result was $70 \%$. Omission of cases with antibiotic residues in milk raised the predictive value of a positive test result to $75 \%$.

The presence of antibiotic residues in a quarter milk sample indicates that the cow might have been treated before the test was performed and the sample collected. In theory, this might in some cases have led to killing of Gram-negative bacteria, with endotoxin still present in milk. Discrepancy between test and culture results is then a logical consequence. In other words, testing milk containing antibiotic residues may produce an outcome which is "correct" (presence of endotoxin), but of doubtful value when the point is to get infor- 
mation of therapeutic relevance. A positive test result in recently treated cows should, therefore, be interpreted with some caution. Destruction of Gram-negative bacteria by the mammary gland defence, leaving endotoxins in the milk, is another possible explanation of a natural disagreement between LAL-test and laboratory results.

The sensitivity of the LAL-test concerning detection of Gram-negative bacteria was $63 \%$. After exclusion of milk samples with antibiotic residues the sensitivity was almost the same $(64 \%)$. Regarding detection of $E$. coli alone, the sensitivity of the test was $68 \%$ for the material as a whole, and $69 \%$ after omission of milk samples with antibiotic residues. The sensitivity was, to some extent, probably underestimated. The laboratory findings, which served as reference, could be questioned in some cases. In 6 of those cases where the LAL-test result was negative and an enterobacteria was isolated in pure culture from the parallel quarter sample, growth of enterobacteria or a mixed flora from samples from other quarters of the same cow indicated contamination.

From some quarter milk samples, just a few colonies of Gram-negative bacteria grew on the agar plate. In these cases, it was not unexpected that the concentration of endotoxins was below the detection threshold of the LAL-test. At least $10^{4}-10^{5}$ C.F.U./ml of Gramnegative bacteria is necessary for a positive LAL-test result (Jonsson and Franklin, to be published). According to Katholm (1989), there is a high frequency of self cure among those cows with coliform mastitis which have a low number of bacteria in milk. Failure to detect Gram-negative bacteria in such cases will hardly lead to negative therapeutic consequences.

The specificity of the test was found to be $97 \%$. Growth of $A$. pyogenes from quarter milk samples was registered in 8 cases. In 3 of these, the LAL-test was positive. A. pyogenes is most often isolated in mixed culture together with Peptostreptococcus indolicus, Stuart Schwan's cocci, Fusobacterium necrophorum and Bacteroides spp. (Jonsson et al. 1991), the 2 latter of which are Gram-negative anaerobic bacteria. In the present study, anaerobic culture was not usually performed when the primary aerobic culture showed bacterial growth. Gram-negative bacteria probably were present together with A. pyogenes, thus causing positive LAL reaction. Apart from $A$. pyogenes, none of the other Grampositive bacteria were associated with a high frequency of false positive test results.

The predictive value of a negative Limulustest result was $96 \%$ for the total material as well as for cases without antibiotic residues in the milk. The real value is probably even higher due to the possible contamination of a few quarter samples. Thus, a negative test result is quite reliable.

In conclusion, the LAL-test is a valuable cowside test for the veterinary surgeon, providing a better basis for selection of antibacterial drug for the initial treatment of clinical mastitis.

\section{Acknowledgements}

The authors thank the veterinary surgeons who performed the field investıgations; Jan Henrik Aubert, Synnøve Dahle, Gudmund Kjørsvik, Arnt Minsaas, Nils Månum, Torolv Røthe, Hans Robert Ske1, Karen Hege Skjeggestad, Harald Solem, Guro Sveberg, and Kristian Wibe.

\section{References}

Bartlett PC, Miller GY, Lance SE, Heider LE · Clinical mastitis and intramammary infections on Ohio dairy farms. Prev. Vet. Med. 1992, 12, 59-71.

Central Veterinary Laboratory: Mastitıs surveillance scheme: July to December 1980 Vet. Rec. 1981, 109, 27. 
Funke H: Klinıska mastiter. Infektionspanorama, klınıska symptom m.m. (Clınical mastıtis. Infectıon panorama, clinical sıgns, etc). Svensk VetTidn. 1983, 35, 707-711.

International Dairy Federatıon: Laboratory methods for use in mastıtıs work. IDF bulletın 1981, document $132,27 \mathrm{pp}$.

Jonsson $P$. Limulustestet - en snabb och enkel metod att påvisa endotoxın från gramnegativa bakterier 1 mjolk vid mastit. (The Limulus test a rapid and simple method to detect endotoxin in mastitic milk). Nord. Vet.-Med. 1985, 37, 298305.

Jonsson $P$, Olsson $S-O$, Olofsson A-S, Falth $C$, Holmberg $O$, Funke $H$ : Bacterılogical invest1gations of clinical mastitis in heifers in Sweden. J. Dairy Res. 1991, 58, 179-185.

Katholm J: Colimastıtıs. Hjemmedyrkning og terapı. (Coliform mastitis. Culture and treatment) Dansk Vet. Tidsskr. 1989, 72, 171-177.

Martın SW, Meek AH, Willeberg P: Veterınary epidemiology. Principles and methods. Iowa State University Press, Ames. 1987.

Roth RI, Levin J, Behr S: A modified limulus amebocyte lysate test with increased sensitivity for detection of bacterial endotoxin. J. lab. clin. med. 1989, 114, 306-311.

Schallibaum M. Mastitis pathogens in Switzerland 1988-1991. IDF Mastitis Newsletter 1993, 18, 20.

Svensk Husdjursskotsel. Årsstatistık inkl djurhalsovård SHS 1990/91 (Annual review from the Swedish Association for Livestock Breeding and Production) 1991, $74 \mathrm{pp}$

Waage S, Nordløkken H, Røn I, Slettbakk T, Solberg I, Østerås O: Mikrobılogıske funn 1 melke- prøver fra kyr med akutt mastıtt. (Organisms in quarter milk samples from cows with acute clinıcal mastitis). Norsk VetTidsskr. 1990, 102, 645654.

White $M E$ Recent research on mastitis from the ambulatory clinic at Cornell and its implications for treatment decisions. Proc. Int Mastitıs Symposium, Quebec, Canada 1987, 217-220

\section{Sammendrag \\ Feltfors $\phi k$ med en test for påvısning av gram-negatıve bakterier $\iota$ melk fra kyr med mastitt.}

Det er foretatt en feltutprøving av en modifisert Limulus amøbocyt lysat (LAL) test som er utviklet for å påvise tılstedeværelse av endotoksınholdıge bakterier 1 mastıttmelk. Elleve praktiserende veterınærer 13 veterinærdistrikter 1 Norge deltok i unders $\varnothing \mathrm{kel-}$ sen. Parallelt uttatte pr $\varnothing$ ver ble unders $\varnothing \mathrm{kt}$ ved et mastittlaboratorium.

For $93 \%$ av de unders $\varnothing$ kte prøvene var det overensstemmelse mellom testresultat og laboratoriefunn. Overensstemmelse angitt ved kappa var 0,63. Testens sensitıvitet med hensyn tıl å påvise gram-negatıve bakterier var $63 \%$, mens spesifisiteten var 97\% For materialet som helhet var den predıktıve verd 1 av et positivt testresultat $70 \%$, av et negativt testresultat $95 \%$. Etter å ha ekskludert prøver der det ble påvist antıbıotıkarester, ble den predıktıve verdı av et positıv testresultat funnet å være $75 \%$, av et negativt testresultat 95\%. LAL-testen anses som et nyttıg hjelpemiddel for praktıserende veterınærer når de skal foreta medikamentvalg ved den initiale behandlıngen av klınıske mastıttılfelle.

(Recelved November 6, 1993; accepted March 18, 1994).

Reprints may be requested from: S. Waage, Natıonal Veterınary Institute, POB 8156 Dep, N-0033 Oslo, Norway or P. Jonsson, Dep. of Veterinary Microbıology, Section of Clinical Microbiology, Swedish Unıversity of Agricultural Sciences, Biomedicum, P. O. Box 583, S-751 23 Uppsala, Sweden. 